\title{
KINERJA TIM BEDAH KAMAR OPERASI RUMAH SAKIT DI KABUPATEN JEMBER
}

\author{
Asmuji $^{1)}$, Priyo Widodo ${ }^{2)}$, Ninik Sumarini ${ }^{3)}$, Iin Indahwati ${ }^{4)}$ \\ 1,2 Fakultas Ilmu Kesehatan. Universitas Muhammadiyah Jember, Indonesia \\ 3,4 Rumah Sakit Daerah Balung, Jember, Indonesia \\ email: asmuji@unmuhjember.ac.id
}

\begin{abstract}
Abstrak
Ruang bedah (kamar operas) menjadi suatu area yang memberikan pelayanan pembedahan dengan resiko kasus kecelakaan yang sangat tinggi. Penerapan 3 fase pembedahan (sign in, time out, dan sign out) menjadi kegiatan wajib yang harus dipatuhi tim bedah untuk mewujudkan program keselamatan pasien. Karena, keselamatan pasien dapat menjadi nilai kinerja tim bedah dalam menjalankan tugas dan tanggung jawabnya. Penelitian ini bertujuan untuk menggambarkan kinerja tim bedah kamar operasi di rumah sakit di Kabupaten Jember. Desain yang digunakan penelitian ini adalah deskriptif observasional. Sampel penelitian ini adalah klien yang mendapatkan tindakan bedah (operasi) dengan jumlah 32 orang diambil secara quota sampling. Alat pengumpulan data yang digunakan adalah Surgical Safety Checklist (SSC) dari WHO. Analisis data yang digunakan adalah deskriptif dengan tampilan data berupa tabel distribusi frekuensi. Hasil penelitian menunjukkan 32 (100\%) klien yang akan menjalani operasi dilakukan sign in sesuai dengan item dalam SSC. Artinya kinerja tim bedah dalam tahapan sign in dalam katagori baik. Kinerja tim bedah pada fase time out dan sign out belum menunjukkan kinerja yang baik. Kinerja tim bedah yang tidak baik dalam kegiatan pembedahan sangat berisiko menimbulkan ancaman keselamatan klien selama menjalani pembedahan maupun setelahnya. Bagi pihak manajemen rumah sakit diharapkan melakukan monitoring dan evaluasi kinerja tim bedah secara berkala dan berkelanjutan.
\end{abstract}

Kata kunci: kamar operasi, kinerja, tim bedah

\begin{abstract}
The surgery room is an area that provides surgical services with a very high risk of accident cases. The implementation of 3 phases of surgery (sign in, time out, and sign out) is a mandatory activity that the surgical team must comply with to realize a patient safety program. Because patient safety shows the work value of the surgical team's performance in carrying out their duties and responsibilities. This study aims to describe the performance of the operating room surgery team at a hospital in Jember Regency. The design used in this research is descriptive observational. The sample of this study was 32 clients who received surgery/surgery which was taken by quota sampling. The collecting data used Surgical Safety Checklist (SSC) from $W H O$. The data analysis used description with the data display in the form of a frequency distribution table. The results showed that $32(100 \%)$ clients who will have surgery were signed in based on the items in the SSC. It showed that the performance of the surgical team in the sign-in stage is in a good category. The performance of the surgical team in the time out and sign out phases has not shown good performance. The substandard performance of the surgical team is very risky to pose a threat to the client's safety during surgery and after surgery. The hospital management is expected to monitor and evaluate the performance of the surgical team regularly and continuously.
\end{abstract}

Keywords: surgery room, performance, surgical team

\section{PENDAHULUAN}

Rumah sakit merupakan organisasi profit/ sosial yang bergerak dalam jasa pelayanan kesehatan yang mempunyai tujuan memberikan pelayanan yang berkualitas. Pelayanan yang berkualitas dapat dinilai dari berbagai macam aspek. Salah satu aspek penting yang menjadi titik penting dalam mewujudkan kualitas pelayanan di rumah sakit adalah keselamatan 
pasien. Pelayanan yang bermutu tidak hanya diberikan pada area tertentu, tetapi semua area harus mendapat layanan yang sama baiknya, termasuk pelayanan pasien di ruang bedah/ kamar operasi.

Ruang bedah/ kamar operasi menjadi suatu area yang memberikan pelayanan pembedahan dengan risiko kasus kecelakaan yang sangat tinggi (Haugen et al., 2013). Sebagian besar $(80,8 \%)$ KTD (kejadian yang tidak diharapkan) terjadi pada waktu klien di rumah sakit, dan $58,4 \%$ berasal dari tindakan pembedahan dari seluruh KTD yang terjadi di rumah sakit. Dari angka KTD tersebut, 41\% nya terjadi di kamar bedah (Vries et al., 2011). Kejadian ini akan diperparah jika proses pelayanannya tidak memperhatikan kondisi pasien, kesiapaan pasien, serta prosedur tindakan yang telah ditetapkan(Firdausi et al., 2020; Haugen et al., 2013; Sukasih et al., 2012).

Kondisi di atas tentu sangat memprihatinkan, sehingga perlu menekan KTD yang terjadi di rumah sakit, terutama di ruang bedah/ kamar operasi dengan menciptakan budaya keselamatan pasien (NHS, 2010). Salah satunya adalah dengan menjaga komunikasi efektif. Komunikasi efektif merupakan bentuk komitmen tim bedah dalam menjaga terselenggaranya pelayanan yang berkualitas. Harus et al., (2015) menyatakan bahwa sistem ini dapat menjadi tindakan prevensi terjadinya kesalahan yang disebabkan oleh karena suatu tindakan atau menghindari tindakan yang seharusnya dilakukan tindakan. JCI (2010); Komisi Akreditasi Rumah Sakit (2011) menyatakan bahwa program sasaran keselamatan pasien harus dikomunikasikan dan diinformasikan dengan baik. Hal ini bertujuan untuk tercapainya: 1) ketepatan dan kebenaran identifikasi klien, 2) meningkatnya komunikasi efektif, 3) peningkatan kewaspadaan dan keamanan obat-obat yang seharusnya diwaspadai, 4) ketepatan lokasi tindakan, ketepatan prosedur tindakan, ketepatan klien operasi, 5) penurunan risiko infeksi dalam pelayanan kesehatan, dan 6) penurunan risiko kejadian pasien jatuh.

Program keselamatan pasien di ruang bedah dapat dilakukan dengan komunikasi yang berupa persamaan persepsi antara ahli bedah, anestesi dan perawat (Weiser et al., 2009) dalam penerapan fase atau tahapan dalam pembedahan yaitu fase sign in, time out, dan sign out yang dituangkan dalam Surgical Safety Checklist (WHO, 2016) sesuai dengan aturannya. Kegiatan komunikasi dengan cara menyamakan persepsi dan penerapan fase di atas dapat menjadi acuan untuk menilai kinerja tim bedah dalam menjalankan tugasnya. Kepatuhan tim bedah dalam menerapkan kegiatan tersebut secara otomatis juga menggambarkan kualitas pelayanan yang ada di ruang bedah/ kamar operasi.

Tujuan penelitian ini adalah menggambarkan kinerja tim bedah kamar operasi di rumah sakit di Kabupaten Jember.

\section{METODE PENELITIAN}

Desain penelitian ini adalah deskriptif observasional yang bertujuan untuk menggambarkan kinerja tim bedah kamar operasi di rumah sakit di Kabupaten Jember. Sampel penelitian ini adalah klien yang mendapatkan tindakan bedah/operasi dengan jumlah 32 orang yang diambil pada tindakan operasi dinas pagi 12 orang, dinas sore 10 orang, dan dinas malam 10 orang secara quota sampling. Instrumen yang digunakan adalah Surgical Safety Checklist dari WHO. Analisis data yang digunakan adalah deskriptif dengan tampilan data berupa tabel distribusi frekuensi.

\section{HASIL DAN PEMBAHASAN}

Keselamatan pasien dan kepuasan adalah jantung dari penyampaian layanan kesehatan (Kemenkes RI, 2017). Keselamatan pasien juga menjadi isu global (Kemenkes RI, 2015). Sehingga kegiatan keselamatan pasien merupakan orientasi mutlak yang harus dijalankan setiap pelayanan kesehatan, termasuk rumah sakit. Unit inti di rumah sakit dengan kegiatan yang penuh risiko dapat menimbulkan KTD (kejadian yang tidak diharapkan) adalah ruang bedah. Sebagai upaya untuk menekan terjadinya KTD di ruang bedah adalah tim ruang bedah mematuhi tahapan kegiatan sign in, time out, dan sign out sesuai dengan Surgical Safety Checklist dari WHO.

\section{Fase Sign In}

Hasil penelitian dalam kegiatan sign in tim ruang bedah/ kamar operasi di rumah sakit diperoleh data pada tabel 1 . berikut: 
Tabel 1. Kinerja Tim Bedah Kamar Operasi dalam Manjalankan Sign In di Rumah Sakit di Kabupaten Jember $(n=32)$

\begin{tabular}{|c|c|c|c|c|c|c|c|}
\hline \multirow{3}{*}{ No } & \multirow{3}{*}{ Kegiatan Sign In } & \multicolumn{4}{|c|}{ Kinerja } & \multirow{2}{*}{\multicolumn{2}{|c|}{ Total }} \\
\hline & & \multicolumn{2}{|c|}{ Baik } & \multicolumn{2}{|c|}{ Tidak Baik } & & \\
\hline & & $\mathbf{N}$ & $\%$ & $\mathbf{N}$ & $\%$ & $\mathrm{~N}$ & $\%$ \\
\hline 1. & Konfirmasi Identitas Klien & 32 & 100 & 0 & 0 & 32 & 100 \\
\hline 2. & Konfirmasi Sisi Pembedahan & 32 & 100 & 0 & 0 & 32 & 100 \\
\hline 3. & Persiapan Mesin Pembedahan dan Anastesi & 32 & 100 & 0 & 0 & 32 & 100 \\
\hline 4. & Pengecekan Pulse Oximetri dan Fungsinya & 32 & 100 & 0 & 0 & 32 & 100 \\
\hline 5. & Konfirmasi Alergi Klien & 32 & 100 & 0 & 0 & 32 & 100 \\
\hline 6. & Konfirmasi Risiko Operasi & 32 & 100 & 0 & 0 & 32 & 100 \\
\hline
\end{tabular}

Tabel 1 menunjukkan bahwa kinerja tim bedah kamar operasi di rumah sakit Kabupaten Jember dalam melakukan kegiatan tahap sign in selama melakukan tindakan operasi, $100 \%$ dalam katagori baik. Hasil kinerja ini menjadi bentuk komitmen tim bedah sudah melaksanakan tugas dan tanggung jawabnya dengan baik. Dampak yang diharapkan adalah KTD mampu ditekan dan klien aman selama menjalani tindakan, sehingga keselamatan klien yang menjalani pembedahan terjaga dengan baik.

Sign in adalah langkah awal kegiatan setelah pasien masuk di ruang serah terima sebelum tindakan induksi anestesi. Tahap sign in dalam kegiatan pembedahan dapat mempengaruhi tahapan berikutnya. Sebagai bentuk tanggung jawab, maka tim bedah dalam kamar operasi harus selalu melakukan tahapan ini tanpa ada alasan apapun.

Kegiatan dalam tahapan sign in berupa komunikasi efektif antar anggota tim bedah (Irmawati et al., 2017). Kinerja tahap sign in dapat diukur dari kegiatan konfirmasi identitas klien, konfirmasi sisi pembedahan, persiapan mesin pembedahan dan anastesi, pengecekan pulse oximetri dan fungsinya, konfirmasi alergi klien, dan konfirmasi risiko operasi (WHO, 2016) sebagai media komunikasi dan kerjasama yang lebih baik antar disiplin klinis (Nurhayati et al., 2019) yang menjadi salah satu kunci kesuksesan dalam tindakan pembedahan.

Komunikasi dan kolaborasi interprofesional dalam ruang bedah menjadi hal mutlak. Kolaborasi akan berjalan dengan baik jika didukung dengan komunikasi efektif. Oleh karena itu Irmawati et al. (2017) menyatakan komunikasi menjadi aspek krusial dalam kolaborasi.

Kolaborasi efektif akan terlaksana jika anggota tim mempunyai kemampuan interprofesional kolaboratif (Irmawati et al., 2017). Kompetensi ini akan sangat mempengaruhi kualitas dari kolaborasi yang berdampak dalam meningkatkan keselamatan pasien, karena melalui komunikasi secara efektif antar profesi dapat menghindarkan kesalahpahaman tidak penting yang menjadi penyebab timbulnya medical error (Irmawati et al., 2017) atau kesalahan dalam bentuk lainnya yang sangat merugikan bagi klien. Karena menurut Yuliana et al. (2018) salah satu penyebab terancamnya keselamatan klien adalah kegagalan komunikasi antar tim kesehatan.

\section{Fase Time Out}

Fase time out merupakan fase setelah pasien diberi tindakan anestesi oleh tenaga anestesi dan sebelum tindakan operasi (Sandrawati et al., 2013; Nurhayati et al., 2019). Kinerja tim bedah kamar operasi rumah sakit di kabupaten Jember dalam menjalankan fase timeout tergambar dalam Tabel 2 berikut: 
Tabel 2. Kinerja Tim Bedah Kamar Operasi dalam Manjalankan Time Out di Rumah Sakit di Kabupaten Jember $(n=32)$

\begin{tabular}{|c|c|c|c|c|c|c|c|}
\hline \multirow{3}{*}{ No } & \multirow{3}{*}{ Kegiatan Time Out } & \multicolumn{4}{|c|}{ Kinerja } & \multirow{2}{*}{\multicolumn{2}{|c|}{ Total }} \\
\hline & & \multicolumn{2}{|c|}{ Baik } & \multicolumn{2}{|c|}{ Tidak Baik } & & \\
\hline & & $\mathbf{N}$ & $\%$ & $\mathbf{N}$ & $\%$ & $\mathrm{~N}$ & $\%$ \\
\hline 1. & Konfirmasi Nama dan Peran Anggota Tim & 12 & 38 & 20 & 62 & 32 & 100 \\
\hline 2. & $\begin{array}{l}\text { Konfirmasi secara Lisan Identitas Pasien, Sisi yang akan } \\
\text { Dibedah, dan Prosedur Pembedahanan }\end{array}$ & 18 & 56 & 14 & 44 & 32 & 100 \\
\hline 3. & $\begin{array}{l}\text { Konfirmasi Antibiotik Profilaksis Telah Diberikan } 60 \text { Menit } \\
\text { Terakhir }\end{array}$ & 21 & 66 & 11 & 34 & 32 & 100 \\
\hline 4. & Antisipasi Peristiwa Kritis & 21 & 66 & 11 & 34 & 32 & 100 \\
\hline 5. & Pemeriksaan Penunjang & 15 & 47 & 17 & 53 & 32 & 100 \\
\hline
\end{tabular}

Tabel 2 menunjukkan bahwa kinerja tim bedah di kamar operasi dalam melakukan konfirmasi nama dan peran anggota tim paling banyak tidak dilakukan. Kondisi tersebut dapat disebabkan oleh karena masing-masing anggota tim merasa sudah saling kenal dan sudah mengetahui masing-masing perannya. Selain faktor di atas Amiruddin et al. (2018) menyatakan bahwa penyebab rendahnya kinerja tim bedah dalam memperkenalkan diri dan perannya disebabkan faktor adanya asumsi bahwa perkenalan diri dalam pelaksanaan pembedahan bukan hal penting. Perkenalan diri antar anggota tim bedah sering kali tidak dilakukan kembali, apabila tim yang sama terlibat lagi pada tindakan operasi berikutnya.

Perkenalan nama dan peran merupakan masing-masing anggota tim bedah pada waktu bertugas adalah hal sangat penting. Karena jika tidak dilakukan dapat menyebabkan ketidaktahuan adanya pergantian anggota tim dan perannya. Padahal kegiatan ini menjadi hal penting, karena Lingard et al. (2008) menyampaikan bahwa perkenalan secara nyata berhasil mengangkat level komunikasi antar anggota tim, mencegah medical error dan keterlambatan dalam bekerja.

Kegiatan dalam time out yang kinerjanya masih banyak yang tidak baik adalah pemeriksaan penunjang. Tidak dilakukannya pemeriksaan ulang dapat disebabkan oleh karena masih ada persepsi bahwa pemeriksaan sudah dilakukan sebelumnya, sehingga tim bedah masih ada yang merasa tidak terlalu dilakukan pemeriksaan lagi. Faktor lain yang dapat menjadi pemungkin timbulnya masalah ini adalah komitmen untuk memberikan pelayanan yang terbaik.
Jika dibandingkan dengan dua kegiatan yang dominan tidak dilakukan dengan baik, terdapat tiga kegiatan lain dalam fase time out sebagian besar sudah dilakukan dengan baik, yaitu: 1. Konfirmasi secara lisan identitas pasien, sisi yang akan dibedah, dan prosedur pembedahan sebesar 56\%; 2. Konfrimasi antibiotik profilaksis sebesar $66 \%$; dan 3. Antisipasi peristiwa kritis sebesar $66 \%$. Walaupun secara data, capaian tersebut lebih dari $50 \%$ kinerjanya sudah baik, tetapi jika melihat data yang kinerjanya belum baik, maka masih rawan timbulnya KTD bagi klien, sehingga masih perlu peningkatan kinerja yang lebih baik.

Konfirmasi identitas klien, sisi pembedahan, dan prosedurnya merupakan kegiatan yang tidak kalah penting bila dibanding dengan kegiatan lainnya. Kesalahan identitas, sisi pembedahan, dan prosedur dapat berakibat fatal dan mengancam keselamatan klien. Tidak terkecuali konfirmasi pemberian antibiotik profilaksis dan antisipasi peristiwa kritis. Menurut Amiruddin et al. (2018) antibiotik profilaksis berguna untuk mengurangi risiko kejadian infeksi akibat luka operasi. Sehingga dapat diperkirakan seberapa besar kejadian infeksi jika pemberian profilaksis tidak atau lalai dilakukan. Begitu pun jika peristiwa kritis yang mungkin timbul tidak dilakukan antisipasi.

Upaya untuk meningkatkan kinerja yang masih belum baik menjadi tanggung jawab bersama, agar KTD tidak terjadi. Karena sekecil apa pun celah negatif/ kelalaian yang dilakukan tim bedah dalam melakukan pekerjaannya dapat memungkinkan timbulnya kecelakaan bagi klien. Kondisi demikian tentu dapat merugikan klien dan tim bedah itu sendiri. 


\section{Fase Sign Out}

Pelayanan kesehatan secara profesional tidak hanya dilakukan pada tindakan-tindakan dan area tertentu. Namun, pelayanan profesional harus dilakukan tanpa mengenal area dan tindakan, termasuk dalam pelayanan di ruang bedah yang berupa pelayanan tindakan pembedahan. Sign out merupakan salah satu komponen dalam Surgical Safety Checklist yang wajib diterapkan sepenuhnya sesuai dengan prosedur yang berlaku. Kewajiban yang menjadi tanggung jawab tim bedah saat menjalankan tugasnya, ternyata belum semua dilakukan. Haryanti et al. (2014) mendapatkan data bahwa dari 3 tahapan pengaplikasian SSC (sign in, time out, dan sign out), fase sign out merupakan tahap yang nilainya terburuk apabila dibanding fase lainnya. Hal ini dikarenakan tim bedah sering tidak melakukannya, baik pada tindakan operasi kegawatdaruratan maupun operasi elektif. Data tersebut di atas pun ditemukan pada penelitian yang tersaji dalam Tabel 3 di bawah:

Tabel 3. Distribusi Frekuensi Kinerja Tim Bedah Kamar Operasi dalam Manjalankan Sign Out di Rumah Sakit di Kabupaten Jember $(\mathrm{n}=32)$

\begin{tabular}{|c|c|c|c|c|c|c|c|}
\hline \multirow{3}{*}{ No } & \multirow{3}{*}{ Kegiatan Sign Out } & \multicolumn{4}{|c|}{ Kinerja } & \multirow{2}{*}{\multicolumn{2}{|c|}{ Total }} \\
\hline & & \multicolumn{2}{|c|}{ Baik } & \multicolumn{2}{|c|}{ Tidak Baik } & & \\
\hline & & $\mathbf{N}$ & $\%$ & $\mathbf{N}$ & $\%$ & $\mathrm{~N}$ & $\%$ \\
\hline & Review Pembedahan & 31 & 97 & 1 & 3 & 32 & 100 \\
\hline & Penghitungan Bahan Habis Pakai dan Instrumen & 22 & 69 & 10 & 31 & 32 & 100 \\
\hline & Labelisasi & 12 & 38 & 20 & 62 & 32 & 100 \\
\hline 4. & Konfirmasi Alat & 12 & 38 & 20 & 62 & 32 & 100 \\
\hline 5. & Peninjauan Pemulihan dan Pengelolaan Klien & 13 & 41 & 19 & 59 & 32 & 100 \\
\hline
\end{tabular}

Tabel 3 menunjukkan tahap sign out masih didominasi oleh kinerja yang tidak baik. Penghitungan bahan habis pakai dan instrumen, serta konfirmasi alat bertujuan untuk menghindari tertinggalnya alat maupun bahan habis pakai di dalam area pembedahan, dan menurut Hermawan et al. (2014) juga untuk menghindari adanya pembedahan ulang.Kondisi semacam ini jika terjadi akan sangat mengancam keselamatan klien.

Kegiatan dalam item ini harus dilakukan secara cermat dan teliti, serta harus dikroscek secara benar dan dipastikan ada kesesuaian antara bahan dan alat yang dipakai di awal dengan setelah tindakan operasi. Kepastian tidak adanya bahan dan alat tersebut yang tertinggal, maka ini dapat menghindarkan tim bedah dari mal praktik dan keselamatan klien dapat terjamin.

Melihat pentingnya mematuhi semua tindakan berdasarkan standar prosedur operasional (SPO) dan efek yang ditimbulkan jika lalai, tidak membuat tim bedah secara otomatis mematuhi SPO yang ada. Potret Sandrawati et al. (2013) menemukan beberapa faktor yang menyebabkan tim bedah tidak mematuhi SPO dalam menjalankan 3 fase pembedahan (sign in, time out, dan sign out), adalah: 1 . Tenaga keperawatan yang kurang dari kebutuhan; 2. Belum memahami tentang pelaksanaannya; 3 . Budaya kerja petugas yang belum terbangun dengan baik (sering lupa); 4. Petugas medis terburu-buru dalam melakukan tindakan; 5. Rendahnya kesadaran akan pentingnya mematuhi SPO pembedahan; dan 6. Komunikasi antara dokter dan perawat yang masih sering kali mengalami hambatan.

\section{KESIMPULAN DAN SARAN}

Tindakan pembedahan dalam ruang bedah/ kamar operasi mempunyai risiko yang sangat tinggi dalam menimbulkan masalah keselamatan klien. Kondisi ini akhirnya dibuatlah fase pembedahan (sign in, time out, dan sign out) yang dituangkan dalam SPO yang mempunyai tujuan untuk meningkatkan keselamatan klien selama menjalani pembedahan dan setelahnya. Namun, kenyataannya dari banyak penelitian masih ditemukan kinerja tim bedah yang tidak baik selama melakukan tugas pembedahan.

Saran bagi pihak manajemen rumah sakit yaitu harus melakukan monitoring dan evaluasi secara berkala untuk memastikan bahwa tim bedah selalu mempunyai kinerja yang baik selama melakukan tugas pembedahan. 


\section{REFERENSI}

Amiruddin, A., Emilia, O., Prawitasari, S., \& Prawirodihardjo, L. (2018). Hubungan kepatuhan tim bedah dalam penerapan Surgery Safety Checklist (SSC) dengan infeksi luka operasi dan lama rawat inap pada pasien seksio sesarea di Rumah Sakit Umum Daerah Kabupaten Barru. Jurnal Kesehatan Reproduksi, 5(3), 145-158. ISSN 2302-836X (print), ISSN 2621-461X (o.

Firdausi, A., Dewi, A., \& Susanto. (2020). Pengaruh akreditasi rumah sakit dalam perubahan tingkat kepatuhan pengisian surgical safety checklist di RS Nur Hidayah. Jurnal Ilmiah Universitas Batanghari Jambi, 20(1), 258-262. https://doi.org/10.33087/jiubj.v20i1.776

Harus, B. D., \& Sutriningsih, A. (2015). Pengetahuan perawat tentang keselamatan pasien dengan pelaksanaan prosedur keselamatan pasien rumah sakit (KPRS) di Rumah Sakit Panti Waluyo Sawahan Malang. Jurnal CARE, 3(1), 25-32.

Haryanti, F., Hasri, E. T., \& Hartriyanti, Y. (2014). Praktik keselamatan pasien bedah di rumah sakit daerah. Jurnal Manajemen Pelayanan Kesehatan, 17(1), 182-187. https://doi.org/https://doi.org/10.9774/jmk.13.1. 61- 75

Haugen, A. S. et al. (2013). Impact of the World Health Organization's surgical safety checklist on safety culture in the operating theatre: A controlled intervention study. British Journal of Anaesthsia.

Hermawan, I., Saryono, S., \& Santoso, D. (2014). Gambaran penerapan surgery patient safety fase sign out pada pasien post operasi bedah mayor di Instalasi Bedah Sentral RSUD Kebumen. Jurnal Ilmiah Kesehatan Keperawatan, 10(3), 124-132.

Irmawati, N. E., \& Anggorowati. (2017). Surgical cheklist sebagai upaya meningkatkan patient safety. Journal of Health Studies, 1(1), 40-48.

JCI. (2010). Joint Commision International Accreditation Standards for Hospitals. USA: JCI.

Kemenkes RI. (2015). PedomanNasional Keselamatan Pasien Rumah Sakit (III).
Kemenkes RI. (2017). Manajemen keselamatan pasien. Bahan ajar keperawatan. Jakarta.

Komisi Akreditasi Rumah Sakit. (2011). Standar Akreditasi Rumah Sakit (4th ed.). Jakarta: Dirjen BUK.

Lingard, L., Regehr, G., Orser, B., Reznick, R., Baker, G. R., \& Doran, D. (2008). Evaluation on of a preoperative checklist and team briefing among surgeons, nurses, and anesthesiologists to reduce failures in communication. Arch Surgical, 143(1), 7-12.

NHS. (2010). Implementing the surgery safety checklist: the journey so far. Ukraina.

Nurhayati, S., \& Suwandi. (2019). Kepatuhan perawat dalam implementasi surgical safety checklist terhadap insiden keselamatan pasien ponek di Rumah Sakit Semarang. Jurnal SMART Keperawatan, 6(1), 25-30-62215236. https://doi.org/10.34310/jskp.v6i1.215

Sandrawati, J., Supriyanto, S., \& Nurul, T. (2013). Rekomendasi untuk meningkatkan kepatuhan penerapan surgical safety checklist di kamar bedah. Buletin Penelitian Sistem Kesehatan, 17(1).

Sukasih, S., \& Suharyanto, T. (2012). Analisis faktor-faktor yang berkontribusi terhadap pasien safety di Kamar Operasi Rumah Sakit Premier Bintaro. Jurnal Health Quality, 2(4), 234-245.

Vries, E. N., Prins, H. A., Crolla, R. M. P. H., Outer, A. J., Ander, G., Helden, S. H., ... Boermeester, M. A. (2011). Effect of a comprehensive surgical safety system on patient outcome. N Eng L JMed, 363(20), 1927-1937.

Weiser, T. G., Regenbogen, S. E., Thompson, K. D., Haynes, A. B., Lipsitz, S. R., \& Berry, W. . (2009). Es ma on of the global volume of surgery: a Modelling Strategy Based on Available Data. Lancet, 372(9633), 139-144.

WHO. (2016). Surgical safety cheklist.

Yuliana, B. W., \& Lubis, V. H. (2018). Analisis kelengkapan pengisian lembar keselamatan pasien di Rumah Sakit Ichsan Medical Centre Bintaro tahun 2017. Jurnal Kesehatan STIKes IMC Bintaro, II(1), 104-108. 